\title{
The effects of leadership traits on transformation: A case study of a South African university
}

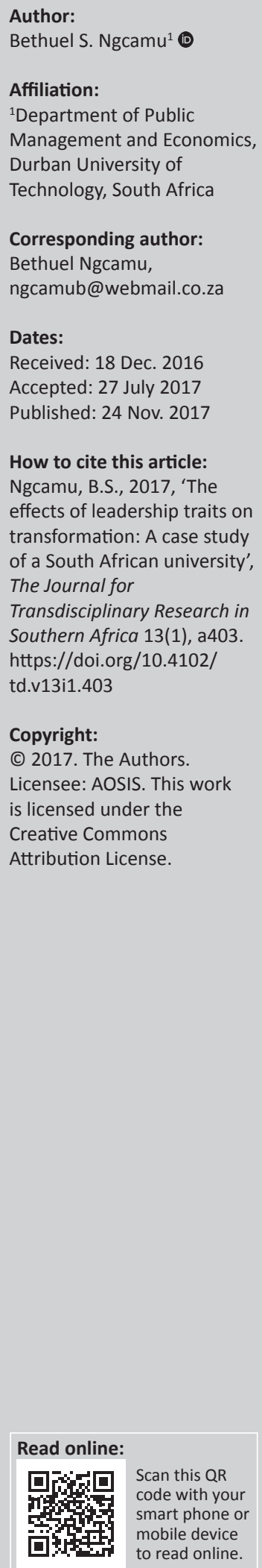

This article investigated the effects of leadership traits on transformation in a merged and incorporated higher education institution in South Africa. Few studies have been conducted on leadership traits in universities, with none linking them to transformation. The study was guided by the traits theory, one of the systematic attempts to study the effect of leadership on transformation. Both quantitative and qualitative approaches were used, the former through a structured survey questionnaire and the latter through in-depth interviews. The questionnaire generated a high reliability rate of 0.947 , indicating a high degree of internal consistency of the results, which reflected nearly $40 \%$ of the research participants who felt that the university creates a platform for open debates. However, $30 \%$ of them did not feel that independent thinking and freedom of speech are promoted, a finding partly corroborated by the qualitative findings. It was also found that business processes were inflexible, there was no reward for performance, unproductive change interventions were introduced and decision-making centralised, all seen as contrary to the transformation agenda and reflecting poor leadership traits. It is hoped that the study will assist university decision-makers under the current state of turmoil in the South African higher education landscape to exhibit leadership traits that will bring about transformation. The study also fills a void in the scant literature on the effects of leadership traits on transformation in South African universities, thus contributing to the body of knowledge.

\section{Introduction}

Currently, South African universities of technology such as Durban Institute of Technology (DUT) are facing crisis relating to realising their transformation agenda. This crisis is characterised by violent protests emanating from a mixture of transformation-related demands, including free education, giving access to more black students, rather than merely promoting academic excellence and aptitude, as well as demands for decolonisation of the curriculum. Leadership traits, considered as contributing to the achievement of the institutional transformation agenda, seem to be lacking amongst leaders of these institutions. Although leadership has been linked to traits and situations (Avolio 2005; Northouse 2010), certain traits are not evident in leaders in universities in South Africa to effect transformation (Bass 2008). This study investigates different categories of leadership traits, including cognitive, social competency, emotional competency, biophysical and traits of character (Bass 2008) and their effect on transformation at DUT which had embarked on restructuring since the merger.

Hall, Symes and Luescher (2004:28) reiterate that the South African restructuring of higher education is unique to the extent that it is driven by a political agenda of transformation, redress and equity which explicitly seeks to break the apartheid mould of higher education. Literature on institutional mergers in South Africa indicates a high degree of stress amongst staff (De Lange \& Olivier 2008; Hay \& Fourie 2002; Reddy 2007; Van der Merwe 2007). The study conducted by Singh (2011:1195) at DUT revealed that participants complained that 'staff are under a lot of stress because of the effects of racism'. For example, Chalufu (2002) indicates that there were major tensions, with a potential clash of institutional cultures, between Natal and ML Sultan Technikons postmerger and incorporation. In view of this, this study ascertains the impact, if any, of leadership traits on transformation in the merged and incorporated DUT. Furthermore, it responds to the question on what leadership traits that have an impact on transformation at DUT.

An interview-based study conducted by Reis (2015:14) on four women university presidents to describe leadership traits identified several themes related to leadership success. It included their responses to barriers in moving through the leadership labyrinth, barriers met that required navigational skills to negotiate, pure luck, and multiple layers of innate traits, commitment to practice, attention to detail and pure perseverance as a platform for leadership success and to 
achieve a leadership position. Another study conducted on a sample of 99 students in two universities and a sample of 92 students at two colleges of education in south-west Nigeria found that coaching leadership traits were preferred by athletes of universities and colleges of education. The results indicated that the traits of friendliness and happiness, sense of humour and cheerfulness, and cooperation were most preferred irrespective of the type of institution (Keinde 2013). The two studies referred to show that few studies were conducted on leadership traits in universities, with none of them linked to transformation or conducted in the South African context. This study fills the gap.

This study investigates the impact of leadership traits on transformation at DUT after its merger and incorporation. What follows next is the literature review, research design and methodology followed by the data presentation, analysis and the discussion of the research findings with the literature reviewed. This article concludes by drawing conclusions and providing recommendations, limitations and advice for future researchers based on the research findings.

\section{History of the Natal Technikon and ML Sultan Technikon}

Technikon Natal was founded in the early 1900s for primary education and to promote education opportunities for Indian people. The Advanced Technical Education Act (No. 40 of 1967) was a watershed for education in South Africa as it provided exclusively for the needs of the white population. Between 1953 and 1965, the provinces shed Bantu education, mixed race education and Indian education and were responsible for white education only. In 1996, more and more non-white students entered what was historically a white institution. Between 1996 and 2002, it shed its white institution image and embraced the challenges of transformation, while addressing issues such as gender equity on campus and restructuring the curricula.

ML Sultan Technikon was established in 1941 as a technical college which was opened on 07 August 1956 to provide educational opportunities for Indian people in then Natal Province. The Technikon Act (No. 125 of 1993) empowered technikons to respond to the challenges of transformation. As the apartheid era began to shut down, it became clear that legislation alone could not address the challenges and changes facing the institution. Transformation needed to be real, not symbolic. The transformation of ML Sultan Technikon was initially characterised by conflict between staff, management and students. During 2001, both staff and students sought strong leadership as ML Sultan Technikon moved beyond its historical status as an Indian institution to one reflecting the demographics of KwaZulu-Natal poised to respond to national developmental needs.

In 2001, the councils of both ML Sultan Technikon and Technikon Natal initiated a merger of the institutions, setting the trend in the transformation of higher education. The official merger of the ML Sultan and Natal Technikons took place on 01 April 2002 and was the first in South Africa. It was followed by the merger of the University of Natal (predominately white people) and the University of Durban Westville (Indian people), resulting in the formation of the University of KwaZulu-Natal. Research into governance implications of merged and incorporated higher education institutions (HEIs) was commissioned by the Council on Higher Education (CHE) in 2002. At that time, only one merger had been completed, which resulted in the establishment of the DUT (formerly ML Sultan Technikon, which had been predominantly Indian, and Natal Technikon, predominantly white people). In 2004, four universities were merged and five followed in 2005 (Hall et al. 2004). It marked a turning point for higher education, representing the first of several tertiary institutional mergers designed 'to create a system that is equitable in its distribution of resources and opportunities, academically and financially sustainable and productive so that it can more actively meet the teaching, skills development and research needs of the country' (Annual Report 2002). In 2003, the newly formed university was named DUT, with a focus on strengthening its academic fundamentals - quality teaching, learning and research - and the nomenclature was changed after the passage of the legislation to include the University of Technology. As a newly merged institution, DUT had to address outstanding issues that created alienation, mistrust and a lack of shared purpose and direction for the future. In 2005, the Council set aside a sum of R2.5 million as a special allocation to advance equity objectives. The institution began identifying promising students to serve as junior staff under a new programme called 'GOOT' ('growing our own timber'). Following a damning assessor's report and the formal dissolution of council, the highest decision-making body at a university in 2006, the Minister of Education appointed an Administrator, Professor Jonathan Jansen, for DUT in August 2006. The task of the administrator was to carry out the functions of council, which included conducting a forensic audit, instituting effective management practices and, eventually, appointing a new council. Up to that point, DUT had suffered poor governance and a compromised management. Governance had, in key areas, become indistinguishable from management. There were all kinds of questions within and outside the institution about financial integrity, low staff morale and a negative public impression about the merged 'university of technology'. It can be deduced from this historical background that the merged institutions were established for only Indian people, excluding African black native people. This background makes it necessary to conduct both qualitative and quantitative research on the leadership traits required to realise the transformation agenda of these institutions, which were established under racially segregated policies (apartheid).

Addressing the equity profile of DUT remains a challenge as the demographic representation amongst academic staff in 2013 was skewed: $42 \%$ Indian people, $28 \%$ black people, $25 \%$ white people, $3 \%$ mixed race people and $2 \%$ designated as 'other' (DUT Annual Report 2013). Representation of staff in administration was given as $48 \%$ black people, $40 \%$ Indian 
people (mostly occupying strategic leadership positions), 8\% white people, $3 \%$ mixed race people and 1\% 'other'. The University's Equity Policy has an elaborate scheme to 'grow our own timber', an existing institutional strategy now referred to as the 'Siyazakhela Programme', which is wholly dependent on the development of a funding mechanism the university is unable to address at present (DUT Annual Report 2013).

\section{Background to the study area}

In the 1990s, restructuring the higher education system as part of the process of redressing the legacies of apartheid and transforming South African higher education focused on the expansion of enrolments, policy focus on redress funding, targeted capacity building and infrastructure provision, while the enrolment figures had dropped and some institutions counted less than half the students (Department of Education 2008:30). According to the Department of Education (2008:85), between 1995 and 1996, the National Commission endorsed the need for transformation of the higher education system and asserted that if the legacy of the apartheid past was to be overcome, higher education would have to be planned, governed and funded as a single coordinated system (Department of Education 2008:31). The National Working Group charted a merger process, which included developing institutional statutes; new academic structures and the integration of academic programmes; new conditions of service and remuneration; coordination of tuition fees; integrating administrative, financial and computer systems and procedures; consolidating budgets; integrating support services such as libraries and student services; utilisation of facilities and infrastructure; reconciling institutional cultures and ethos; and development of a social plan (NWG 2001:55).

In 2002, the Ministry of Education accepted a recommendation by the NWG, which remained original, consistent key premises for all mergers: that mergers should produce institutions with a completely new identity and mergers were mandatory and voluntary (Asmal 2002). Universities were reduced from 36 to 11 universities, 5 technikons, 3 'comprehensive institutions' and 2 National Institutes for Higher Education (Asmal 2002), and Section 23 of the amended Higher Education Act (No. 101 of 1997), which outlines the process the Minister must follow to effect mergers, was amended in 2001 and 2002. Earlier developments, such as the publication of a Standard Institutional Statute in 2002, are also of significance to mergers (Asmal 2002).

The Audit Report of the Higher Education Quality Committee (HEQC 2008:6) highlighted that DUT had developed a number of strategies to support its Employment Equity Plan (2003-2008), including 'growing our own timber' project. Black acedemics and mixed race academics studying for higher degrees were appointed on a contract basis and, upon successful completion, were offered full-time appointments. The report revealed that 5 years into the merger DUT was still struggling to develop a new organisational culture to overcome previous institutional allegiances. The HEQC Panel heard in a range of interviews with management, staff and students that DUT is still a fractured institution along the lines of race and technikon-of-origin. The governance and leadership crisis which has affected the institution has compounded some of these problems. The Audit Report (2008) found that during interviews with Executive Deans and heads of departments, the Panel learned that academics generally do not participate in staff development initiatives. However, during interviews with staff, the Panel heard that high workloads make it difficult for them to attend these workshops. The Panel found that there is a large discrepancy between the workload policy targets and the actual workloads of staff. Furthermore, knowledge of staff development opportunities was uneven across the campuses (Audit Report 2008:17).

It was felt that the goals of the merger of the DUT (between ML Sultan and Natal Technikons) were not clearly stipulated (May \& Mason 2007). The DUT, the research site, was formed from the merger of an Indian (ML Sultan Technikon) and a white technikon (Natal Technikon) in 2002 (Chalufu 2002). While the management of both technikons agreed to the merger, and the white Technikon pushed strongly for it, as it was in financial difficulties, staff at ML Sultan resorted to lawsuits to attempt to block it (Chalufu 2002). The racial composition of staff reflects the demographics of the original institutions: a strong representation of Indian people and white people that follows closely on the patterns at ML Sultan and Natal, respectively (Chalufu 2002), and a predominance of men. Postmerger and incorporation at the DUT, Hemson and Singh (2010) have noted anger amongst staff of different racial groups and races. This has been confirmed by Chalufu (2002) that major tensions in DUT, with the potential clash in an era of great institutional cultures, frequent disruptions and changes in senior management, have been observed. Du Pre (cited in the Annual Report 2008:2) mentions that while it was a voluntary merger, it nevertheless had the usual number of challenges and problems faced by all other institutions which merged as part of the changed South African higher education landscape in 2004 and 2005.

\section{Conceptual framework}

According to Bass (2008), patterns of traits are consistent with successful leaders. Bass (2008:103) defined traits required for leadership as 'competencies'. Zaccaro and Banks (2004:104) define leader traits as an integration of personal characteristics that foster a consistent pattern of leadership performance across a variety of group and organisational situations that include both cognitive ability and various personality attributes. According to Yukl (2006), 'traits' refers to a variety of individual attributes, including aspects of personality (e.g. self-confidence, extroversion, emotional maturity and energy level), needs and motives (guide, energy and sustained behaviour) and values (internalised attitudes about what is right and wrong, ethical and unethical, moral and immoral). Examples of values include fairness, justice, 
honesty, freedom, equality, loyalty, excellence, courtesy and cooperation. Against this background, this study seeks to determine whether these leadership traits impact transformation in this university.

The term 'leadership' has multiple connotations. However, for the purpose of this study, it denotes institutional leaders who use their traits to effect transformation. The study does not intend to resolve different interpretations and understandings of leadership. According to Okumbe (1998), leadership is a process of encouraging and helping others to do something of their own volition, neither because it is required nor because of fear of consequences of noncompliance. Specific traits correspond to effective leadership (Bass 2008; Bono \& Judge 2004; Carlyle 1869; Costa, Terracciano \& McCrae 2001; Derue et al. 2011; Kirkpatrick \& Locke 1991). The previous authors indicate that leadership traits are organised in five categories, including cognitive traits, social competency traits, emotional competency traits, biophysical traits and traits of character. According to Bass (2008:103), cognitive traits 'provide task competence and problemsolving abilities' and include intelligence, judgement, decisiveness, knowledge, fluency of speech, resourcefulness and technical abilities. The concept of transformation is multifaceted, multidisciplinary and multiperspectival with various scholars relating it to various variables including race, efficiency, change, organisational strategy and structure, systems and processes and capabilities (Francis \& Hemson 2010; Meyer \& Botha 2004; Ntshoe 2004; Oloyede 2007; Seedat, Khoza-Shangase \& Sullivan 2014:69). Powell (2001:17) defines change as any activity that alters the current state within an organisational or sociological setting. Moran and Brightman (2000) define change management as the process of continually renewing an organisation's direction, structure and capabilities to serve the ever-changing needs of external and internal customers. The researchers state that change management 'is really about managing (either well or poorly) the impact of some particular environment and/or organisational change on these core activators of workplace performance'. There is a paucity of published data on the relationship between leadership traits and transformation in universities, which this study attempts to address in a university of technology.

\section{Theoretical framework}

Traits leadership theory has grown from a list of inheritable qualities (Bass 2008; Carlyle 1869) to a theory of leadership (Northouse 2010). A historical difficulty in examining leadership traits has been lack of a valid and reliable measurement (Barker 2001; Bass 2008; Northhouse 2010). Some studies have attempted to quantify traits for leadership analysis (Bass 2008; Kirkpatrick \& Locke 1991; Lord, De Vader \& Alliger 1986; Mann 1959). However, with the emergence of the five-factor model of personality (McCrae \& Costa 1987) or the Big 5, a reliable framework of personality traits emerged to support leadership research (Judge et al. 2002). Characteristics that comprise the Big 5 are neuroticism, extraversion, openness, agreeableness and conscientiousness.
Traits theory focuses exclusively on the role of the leader in leadership and provides a deeper and more intricate understanding of how leaders and their personalities are related to the leadership process (Mat 2008).

Traits theory has some limitations, amongst which is the lack of a standard list of traits introduced. It is also linked to the assumption that leaders are born (Mat 2008). Traits theory has been criticised for being ill-defined and difficult to replicate in leadership development (Northouse 2010). The most noticeable aspect of this theory is that successful leaders all over the world and throughout history are born with innate qualities such as personality traits, social traits, ability traits and physical traits (Ng'ethe, Namusonge \& Iravo 2012:299). Stodgil (1948) outlines eight traits, namely: intelligence, alertness, insight, responsibility, initiative, persistence, selfconfidence and sociability. Leadership traits and characteristics have been categorised by Jago (1982) and Daft (1983) who divide them into four groups, namely: personality, social, ability and physical traits (Mat 2008). The theory is very useful in differentiating leaders from followers, effective from ineffective leaders and higher echelon from lower echelon leaders. While this study is guided by the traits theory, it takes advantage of the limitation of the theory as there is no standard list of traits that can bring transformation to any institution, including universities.

\section{Literature review Effects of mergers on institutions and cultures}

Researchers have noted numerous difficulties encountered by merging institutions. These include: anger amongst staff of different racial groups, racism (Hemson \& Singh 2010), funding shortages (Green \& Hayward 1997; Kulati 2000:185) and an inability to retain black staff (Soudien Report 2008:54) in HEIs in South Africa. The research context is the South African higher education landscape, which has seen extensive change ranging from the fundamental reorganisation of the distribution and character of higher education curricula governed by a national qualifications authority to the reconstruction of the academic workplace (Ensor 2006). Government-mandated mergers between 2002 and 2004 reduced the number of South Africa HEIs from 36 universities and technikons to 23 new institutions. Cohen (2006) observed that the Nelson Mandela Metropolitan University, a merger between University of Port Elizabeth (PE), PE Technikon and Vista University, was the subject of legal action, several resignations and dissatisfaction by staff, who had to re-apply for their posts after the merger. Kavanagh and Ashkanasy (2006) explain that the purpose of mergers, closures and incorporations is to streamline for efficiency, with the focus on financial stringency and the achievement of diversity, growth and rationalisation.

However, there was strong opposition to the mergers and it was contended that the process was driven by government through a mixture of politics, legislation and persuasion (Jansen 2003). Schultz (2009) echoes the sentiment that mergers have been a major and highly contested theme in 
higher education in the past decade. In the South African context, research shows that a political decision was made to change the higher education landscape. This has had the unintended effect of lower levels of organisational commitment and potentially lower employee job performance in merger-bound HEIs as a result of the 'slap-dash' manner in which the restructuring occurred.

In an era of great transformation in South African education in early 2000, mergers and incorporations became a key strategy. In 2001, the CHE established a task team on governance to investigate the state of governance in higher education, which resulted in a policy report. The configuration of the landscape of public higher education in South Africa, as per proposals on mergers and incorporations, was accepted in May 2002 (Hall et al. 2004). The aftermath of merged and incorporated universities, including DUT, has compelled leaders to promote a culture of silence, which has limited autonomy and academic freedom. Achieving the transformation agenda in South Africa has been based on compliance to government only with inconspicuous impact on institutions, faculties, departments and individuals. This study is framed on the perception that South African universities tend to ignore certain leadership traits which have a direct effect on transformation, including freedom of speech, independent thinking, flexible business processes and meetings with clear outcomes. The link between leadership traits and transformation is sparsely researched in South African universities.

According to Charney (2006:35), leaders spend a good portion of their time in meetings and much of that time is wasted. However, some researchers have focused solely on open debates (Heifetz, Kania \& Kramer 2004; Ramphele 2008) as the way to provide solutions to problems encountered in South African universities. There is a paucity of published data on the causal link between leadership traits and transformation and it is within this void this study attempts to link the effect of leadership traits on transformation. The politicisation of South African universities has led leaders to be indecisive and emotional, with less interest in responding to institutional stakeholders' needs (Ngcamu 2015: 208a \& 233b). Leaders of DUT do not apply effective leadership styles, although their influence on transformation is important (Ngcamu \& Teferra 2015a: 408). The study conducted at DUT by these researchers on factors influencing transformation revealed that leaders were not listening to the university stakeholders, including employees, and failed to respond to transformation challenges, which can be regarded as counter transformative. A study on the skills development programmes' influence on the realisation of the transformation agenda at DUT revealed that such programmes were accidental as training offered was irrelevant and unresponsive to academics' particular needs (Ngcamu \& Teferra 2015b:130).

\section{Leadership and decision-making in universities}

A study by McGrath (2015) exploring the application of management and leadership techniques in universities found that management style was either particularly democratic or autocratic, while staff noted that freedom has lessened over the years. Several researchers (Amzat \& Idris 2012; Bryman 2007; Lumby 2012; Siddique et al. 2011) indicate that leadership in university pressures: employees expect various features, including autonomy, consultation over important decisions and 'covert leadership' (Mintzberg 1998). Thomas and Thomas (2011:530) argue that leadership uses critical and constructive debates, communication, open examination and 'thinking outside the box' in order for the academia to be successful. A study conducted on 112 staff at the University of Lagos in Nigeria by Solaja, Idowu and James (2016) suggested that university leaders should mainstream all employees in the decision-making processes, which will increase creativity and innovation amongst them. Coates et al. (2010:381) mention major features of a conducive university arena, which include administrative efficiency, autonomy and the involvement of employees in the decisionmaking structures. 'Human-oriented leadership styles increase job satisfaction and several studies have demonstrated that participative decision making can be beneficial to workers' mental health and job satisfaction' (Chen \& Silverthorne 2005:282). Other researchers (Charney 2006:30; Coates et al. 2010:386) argue that employees who participate in decisions benefit from improved self-esteem, low resignations, increased performance and customer service excellence. Fullan and Scott (2009) mention attributes of change-capable universities, which include vigorous, transparent decision-making and determination of priorities. Meanwhile, Mabelebele (2013:6) mentions definiteness of decision as personal attributes for leaders to be successful in a university. The current study investigates whether decisionmaking as a trait is centralised or decentralised and its effect on transformation at DUT.

\section{Academic and administrative staff members' relationships}

Holton and Phillips (1995:43) argue that complaints on poor support from administrative support and the administrative staff's lamentations on the unclear activities of the academic staff members are recurring in universities. There are a number of researchers who have described the relationship between academic and administrative staff members as uneasy and ambivalent (McInnis 1998:161): a less cohesive, 'us versus them' mentality, 'opposing camps' on campus (Kuo 2009:49). They further characterise academic staff as anarchists (Kuo 2009:49) and view administrative culture as 'stuck in slow motion, blissfully ignoring efficiency and leadership' (Meyer \& Kaloyeros 2005:16). Emanating from the above arguments, this study further investigated leadership traits that ensure both academic and nonacademic staff members work collectively, while realising the transformation agenda.

\section{Change and transformation in South African universities}

Fullan and Scott (2009) list attributes of change-capable universities, which include vigorous, transparent decision- 
making and determination of priorities. Abrahamson (2004:10) refers to 'change without pain' (actually change with less pain than usual) and argues that some organisations, when faced with relentless external challenges, make the mistake of engaging in repetitive change syndrome. The result is a combination of initiative overload, change-related chaos and employee burnout cynicism. Scott, Coates and Anderson (2008) argue that effective higher education leaders not only take an active role in making specific changes happen by engaging people in the process of personal and institutional change and improvement, but also help reshape the operating context of their institutions to make them less change averse, more efficient and agile. McMurray et al. (2012:366) concur that these activities require strategies for change management, including the need for senior leaders to value the development of managerial skills amongst middlelevel academics. These researchers emphasise that leadership fosters change and transformation (Herbst \& Conradie 2011:2) and copes with the challenges of inevitable change (Fullan \& Scott 2009:110). Davis, Van Rensburg and Venter (2014) argue that HEIs do not adapt to change as fast as changes that occur in the environment and postulate that collegial governance is dominated by traditional academic structures and practices (aligned with guild-like interest) that lead to the creation of irrationalities and inefficiencies in the systems and its institutions' subordinates. In the aftermath of mergers and incorporations of South African HEIs, shortfall in leadership capability of managing radical changes, from individual employees, departments, institutional and other key stakeholders has been witnessed. Effective change management should consider soft human issues which would avoid resistance to change amongst employees (Mabin et al. 2001; Moran \& Brightman 2000; Mumford 1999). This study is informed by ideas proposed by these researchers. However, an extension is made in investigating whether interventions of change conducted within DUT are productive, including leadership development.

\section{Research methodology}

This study embraced a positivist perspective, as perceptions were discovered, measured and manipulated through a structured questionnaire (McKenna 2003:217) and an interpretivist perspective (Saunders, Lewis \& Thornill 2007:103) as the study investigated the effect of leadership traits on transformation at the DUT by using in-depth interviews. A mixed-methods approach was used (Creswell \& Zhang 2009) with a structured questionnaire that involved a large number of employees in leadership positions, enabling some quantification of findings, and open-ended interviews targeting middle- and senior-level university management. A lack of valid and reliable measurement of leadership traits (Barker 2001) prompted this researcher to use mixed research method in examining the effect of leadership traits on transformation based on traits theory. A structured questionnaire was used and in-depth interviews conducted to ascertain leadership traits that have an effect on transformation in the merged university of technology under study. The study was guided by leadership traits theory to investigate whether leaders in this university promote independent thinking, freedom of speech, open debates, rewards, employee growth, flexible business processes and decentralisation of decision-making. The study also assesses whether the convening of meetings with clear outcomes, productive interventions and collegiality in the institutions can be mentioned as leadership traits that can drive transformation. In-depth interviews targeting university leaders in middle and senior management positions were conducted. The interviews were piloted on middle-level and senior leaders to gauge the effects of leadership traits factors on transformation. As Jansen (2005:308) notes, research on organisational change and educational reform increasingly recognises the need to acknowledge the significance of feelings.

\section{Ethical considerations}

Permission to conduct this study was sought from Durban Institute of Technology management and an ethics certificate was obtained. At the same time, confidentiality and anonymity of participants were maintained.

\section{Quantitative research approach}

Quantitative research is described as a collection of numerical data exhibiting a view of the relationship between theory and research (Bryman 2004:3). The present study was also based on the quantitative research approach, wherein descriptive statistics, namely measures of central tendency and measures of dispersion, were used to describe the distribution of scores on each variable and by determining whether the scores on different variables were related to each other. Ghauri and Gronhaug (2005) argue that a quantitative design is essential as it deals with a large number of respondents and use of numbers to generalisable comparisons and conclusions about populations. In this study, a survey research design addressed the subdimensions, including the effect of leadership traits on transformation.

This study used stratified random sampling, which is a modification of random sampling in which a researcher divides the population into two or more relevant and significant strata based on one attribute or a number of attributes (Lewis, Kaufman \& Christakis 2008:215-223). The sample size was 191 respondents between Peromnes Grades 8 and 6) distributed equitably between academic and nonacademic staff as per the Sekaran (1992) sample table. As this study used probability sampling, the sample size of 191 was ideal to test for the reliability and validity of findings. According to Saunders, Lewis and Thornhill (2007:210), the larger the sample size, the lower the error in generalising from the population.

\section{Qualitative semistructured interviews}

The qualitative aspect of this study used non-probability purposive sampling (Babbie 2004:166), where 28 university 
staff in middle and senior management positions were surveyed. Interviews were used in this study to obtain information on leadership traits' effects on transformation, postmerger and incorporation, and the nature of transformation. As this study is located within the discipline of leadership and transformation in HEIs, Anderson, Sweeney \& Williams (2006:226) assert that research objectives, questions and strategy should be informed by non-probability sampling. Indepth interviews were conducted with 28 academic and nonacademic staff between Peromnes Grades 1-5 as well as key stakeholders, including representatives of trade unions and the Student Representative Council (SRC). These included faculty deans, executive management members, and registrar and director of human resources and finance, respectively. Furthermore, academic heads of departments, a research director, director for quality directorate and marketing and communication were interviewed. This study also used document analysis, which is a systematic procedure for reviewing or evaluating documents both printed and electronic (computer-based and Internet-transmitted) (Bowen 2009:27). DUT annual reports and government documents were reviewed as part of this study. Document analysis yields data excerpts, quotations or entire passages that were organised into major themes, categories and case examples, specifically through content analysis (Labuschagne 2003).

\section{Data collection and analysis}

A total of 191 structured questionnaires were disseminated to the university leaders with 133 completed without any errors, generating a response rate of $70 \%$. To ensure confidentiality, the questionnaires were distributed and collected by the researcher. The reliability of the questionnaires and results was tested and a reliability coefficient of 0.947 was found and accepted. The data gleaned from the structured questionnaires were analysed with Statistical Packages for Social Scientists (SPSS) version 24 for data capturing, presentation, analysis and interpretation. The qualitative findings were triangulated with structured interviews directed at the research participants between junior and middle leadership levels. NVivo software (version 10) was used for organising, analysing and sharing data. Themes gleaned from in-depth interviews were categorised into nodes or themes.

\section{Measuring instruments}

As the research participants were leaders and well educated, the questionnaires were filled without any assistance. Items in the questionnaire were based on 10 leadership traits that may have an effect on transformation, namely: independent thinking (Zide 2010), freedom of speech and open debates (HEIAAF 2008), rewards for performance (Mumford 1999; Rowley 1996), avenues for personal growth (Ngcamu \& Teferra 2015a or 2015b), business processes (Aggarwal 1998; Singh 2001), decision-making (Mabelebele 2013; Olayo 2005), meetings with outcomes (Fourie 1999; Murphy \& Curtis 2013), interventions of change (Meyer \& Botha 2004) and administrative and academic staff relationship (Kuo 2009;
McInnis 1998). The questionnaire had a five-point Likert scale, ranging from 1 (strongly disagree) to 5 (strongly agree). Both qualitative and quantitative data were collected between June and November 2015.

\section{Results of the study}

The research findings show that there is no valid and reliable measurement of leadership traits (Baas 2008) and there are contradictory perceptions regarding the effect of leadership traits on transformation in the university. The research findings presented and analysed in the following sections show that different facets of leadership traits from different authors have positive or negative effects on transformation at the university. Leadership traits include the Big 5 framework of leadership traits (McCrae \& Costa 1987), Bass (2008) and Stodgil's (1948) eight leadership traits.

In all, 132 respondents were sampled comprising 57\% male respondents and $43 \%$ female respondents. There were $27 \%$ of participants with experience between 11 and 15 years, followed by $26 \%$ with 21 years and above, 14\% with between 6 and 10 years and $14 \%$ with between 16 and 20 years of experience. The staff categories were divided into academic (51\%), administrative (28\%), academic support $(8 \%)$, technical services staff $(8 \%)$ and other (5\%). The study participants comprised junior management team (64\%) and middle management (36\%).

The research findings indicate that there is a need for improvement regarding the impact of leadership traits on transformation. This implies the need to prioritise when leadership development programmes are conducted on leadership traits that impact on transformation. A frequency and cross-tabulations analysis was undertaken to determine the exact areas where attention is needed. A more detailed quantitative and qualitative comparison is discussed in the next section.

Most of the research participants (45\%) observed that independent thinking is promoted in the university. However, $31 \%$ of the participants had a different view, which is close to the number of 'undecided' respondents (25\%). Furthermore, findings of the study show that majority of respondents (48\%) support the notion that freedom of speech is promoted in the university, with $29 \%$ holding the opposite view and $23 \%$ undecided. The data indicate comparable views between promotion of independent thinking and freedom of speech. The qualitative research findings are in agreement with the quantitative findings that the Vice Chancellor built trust with employees regarding the university's direction through consultation, promotion of freedom of expression without fear, transparency and inclusiveness, integrity and caring for people, having his feet on the ground and hard work. This is exemplified by the following remarks by one academic head of department (HoD):

The Vice Chancellor (VC) allows transparency and people to speak or talk, inclusive whereby workshops were conducted where all stakeholders talk, integrity, honesty and caring for the people. The VC has sufficient passion and sufficient political will. 
The results indicated that $38 \%$ of the respondents felt that leaders do not create platforms for open debates, which is the greatest degree of disagreement found in the study, while $35 \%$ of the respondents had a positive opinion regarding this theme. This high disagreement is echoed by the low mean difference (2.962), displaying opposite views of the participants. The majority of the academics (41\%), followed by administrative leaders (29\%), disagreed with the view that leaders create platforms for open debates in the institution. The respondents highlighted excessive consultations at all levels, involvement in decision-making, participation, including all stakeholders, responsiveness to the needs of staff, openness to suggestions and communicating on council resolutions, which is contrary to the above findings. This was confirmed by the director:

At DUT, there have been lots of consultation, and people feel, on average, they are taking part and are involved in decisionmaking, what we need to see is implementation, monitoring and evaluation, which means you look at the impact of what is being done in terms of broader communities.

Table 1 shows that $43 \%$ of the respondents agreed rewards for performance are encouraged in the university, the same percentage as those who disagreed with the impact of open debates.

Table $2 \mathrm{a}$ and $2 \mathrm{~b}$ show a perfect agreement between the statement that rewards for acceptable performance are encouraged and job categories at 0.002 level of significance (chi-square). Respondents in both academic and administrative categories equally disagreed and agreed (59\%) with this statement, respectively. While $59 \%$ of the junior management staff members agreed and middle management (36\%) disagreed with the statement, the chi-square test $(0.063)$ indicated no relationship.

Table 1 shows that $46 \%$ of the subjects felt that leaders create avenues for personal growth in the university. A quarter of them had opposite views, which were supported by respondents through in-depth interviews. The view that a hierarchal academic structure does limit leadership opportunities within the university was expressed by the director:

Personal growth happens accidentally, there are no management development programmes and lack of succession planning in this university. Number of initiatives that have been in place to attend skills development programmes under HESA, and there is training on leadership; HESA offers it with no direct effect, monitoring and evaluation tools are non-existent.

Internal training programmes were mentioned as contributing little to the transformation of the university. This sentiment was echoed by the academic HoD:

Skills development is a waste of time and energy as in the past years we were asked to fill in our training needs, including quotations and costs but nothing was done. I've had staff members who wanted to do skills courses through UNISA, but the skills development office declined it. The skills development office promotes academic staff to grow vertically, and administration staff is allowed to attend. Trainings are accidental, and programmes I've attended, I sourced them myself through the skills development fund. People become fatigued in attending these trainings, and no-trainings must happen as routine and must be an integral part as managers.

Table 1 indicates that $43 \%$ of the subjects felt that decisionmaking was centralised. Twenty-five per cent $(25 \%)$ of the respondents had the opposite views. This finding was supported by a high mean difference of 3.323 , indicating that most leaders were positive regarding this statement. The highest agreement in this finding was supported by the academic HoD, who said:

In this university, there is no devolution of power, and delegation of authority has become very weak as line managers cannot take decisions while too much power is vested on one person.

Table 1 shows that $43 \%$ of the study participants had a positive opinion regarding time for meetings with clear

TABLE 2a: Cross-tabulations between 'at my university rewards for acceptable performance are encouraged' and job categories.

\begin{tabular}{lccccc}
\hline Decision & \multicolumn{5}{c}{ Job categories } \\
\cline { 2 - 6 } & Academic & $\begin{array}{c}\text { Academic } \\
\text { support }\end{array}$ & Administration & $\begin{array}{c}\text { Technical } \\
\text { services }\end{array}$ & Other \\
\hline Disagree & $37 \%$ & $0.0 \%$ & $57 \%$ & $20 \%$ & $29 \%$ \\
Undecided & $25.0 \%$ & $36.4 \%$ & $16.2 \%$ & $0.0 \%$ & $0.0 \%$ \\
Agree & $38 \%$ & $64 \%$ & $27 \%$ & $80 \%$ & $77 \%$ \\
\hline
\end{tabular}

TABLE 2b: Chi-square tests.

\begin{tabular}{lccc}
\hline Variable & Value & Df & Asymp. sig. (two-sided) \\
\hline Pearson chi-square & $37.253 \dagger$ & 16 & 0.002 \\
Likelihood ratio & 43.892 & 16 & 0.000 \\
Linear-by-linear association & 0.345 & 1 & 0.557 \\
$N$ of valid cases & 133 & & \\
\hline
\end{tabular}

$\dagger$ Sixteen cells $(64.0 \%)$ have expected count less than 5 . The minimum expected count is 0.53 .

TABLE 1: Leadership traits' effects on transformation.

\begin{tabular}{|c|c|c|c|c|c|c|}
\hline Leadership traits & Strongly disagree & Disagree & Undecided & Agree & Strongly agree & Mean difference \\
\hline Independent thinking is promoted & 8 & 23 & 25 & 34 & 11 & 3.158 \\
\hline Freedom of speech is promoted & 9 & 20 & 23 & 35 & 13 & 3.233 \\
\hline Leaders create a platform for open debates & 12 & 26 & 26 & 24 & 11 & 2.962 \\
\hline Rewards for acceptable performance are encouraged & 16 & 22 & 20 & 35 & 8 & 2.962 \\
\hline Leaders create avenues for personal growth & 11 & 15 & 28 & 38 & 8 & 3.165 \\
\hline Business processes are flexible & 8 & 23 & 35 & 29 & 5 & 3.015 \\
\hline Decision-making is centralised & 2 & 23 & 32 & 26 & 17 & 3.323 \\
\hline There is time for meetings with clear outcomes & 5 & 22 & 30 & 38 & 5 & 3.150 \\
\hline Interventions of change are productive & 7 & 23 & 33 & 29 & 8 & 3.098 \\
\hline Both administrative and academic staff work collectively & 10 & 23 & 23 & 32.3 & 13 & 3.158 \\
\hline
\end{tabular}


outcomes in the university. A little more than a quarter had the opposite perception, with $30 \%$ undecided. Thirty-eight per cent of the respondents agreed that interventions of change were productive in the university. About 30\% had different views and about the same percentage of respondents were undecided.

The cross-tabulations (Table $3 a$ and $3 b$ ) between interventions of change as productive and tenure had the highest agreement (42\%) amongst respondents with 6-10 year experience. However, 39\% of those with 11-15 years of experience disagreed, but the chi-square test revealed no positive intercorrelations (0.056).

Table 1 indicates that $45 \%$ of the respondents hold positive views on the perception of the relationship between administrative and academic staff. About a third, however, had contrary view. Qualitative findings indicated that core administrative departments such as human resources, finance, maintenance and procurement have been inefficient and ineffective. Dilapidated buildings are caused by poor or a lack of maintenance. This was echoed by the academic HoD:

You try to deal with Finance, HR and maintenance - it is difficult, and the executive management must do something about these departments as you cannot see a decent thing done by these departments. Buildings are old, dilapidated and falling apart.

TABLE 3a: Cross-tabulations between 'at my university, interventions of change are productive' and tenure.

\begin{tabular}{lccccc}
\hline Decision & \multicolumn{5}{c}{ Tenure } \\
\cline { 2 - 6 } & $\mathbf{0 - 5}$ & $\mathbf{6 - 1 0}$ & $\mathbf{1 1 - 1 5}$ & $\mathbf{1 6 - 2 0}$ & 21 and above \\
\hline Disagree & $\mathbf{2 7}$ & 55 & $\mathbf{1 1}$ & $\mathbf{3 9}$ & $\mathbf{2 3}$ \\
Undecided & 35.3 & $\mathbf{3 6 . 8}$ & $\mathbf{2 2 . 2}$ & 55.6 & $\mathbf{2 6 . 9}$ \\
Agree & 38 & 42 & $\mathbf{3 9}$ & 33 & 35 \\
\hline
\end{tabular}

Table 3b: Chi-square tests.

\begin{tabular}{lccc}
\hline Variable & Value & Df & Asymp. sig. (two-sided) \\
\hline Pearson chi-square & $25.868 \dagger$ & 16 & 0.056 \\
Likelihood ratio & 30.164 & 16 & 0.017 \\
Linear-by-linear association & 0.977 & 1 & 0.323 \\
$N$ of valid cases & 133 & & \\
\hline
\end{tabular}

$\dagger$ Twelve cells (48.0\%) have expected count less than 5 . The minimum expected count is 1.22 .

TABLE 4a: Cross-tabulations between 'administrative and academic staff work collectively' and job categories.

\begin{tabular}{lccccc}
\hline Decision & \multicolumn{5}{c}{ Job categories } \\
\cline { 2 - 6 } & Academic & $\begin{array}{c}\text { Academic } \\
\text { support }\end{array}$ & Administration & $\begin{array}{c}\text { Technical } \\
\text { services }\end{array}$ & Other \\
\hline Disagree & $40 \%$ & $0.0 \%$ & $35 \%$ & $0.0 \%$ & $14 \%$ \\
Undecided & $24 \%$ & $9.1 \%$ & $24 \%$ & $30.0 \%$ & $14.3 \%$ \\
Agree & $37 \%$ & $91 \%$ & $41 \%$ & $50 \%$ & $0.0 \%$ \\
\hline
\end{tabular}

TABLE 4b: Chi-square tests.

\begin{tabular}{lccc}
\hline Variable & Value & Df & Asymp. Sig. (two-sided) \\
\hline Pearson chi-square & $43.772 \dagger$ & 16 & 0.000 \\
Likelihood ratio & 40.277 & 16 & 0.001 \\
Linear-by-linear Association & 3.978 & 1 & 0.046 \\
$N$ of valid cases & 133 & & \\
\hline † Seventeen cells $(68.0 \%)$ have expected count less than 5. The minimum expected count is \\
$\begin{array}{l}0.68 .\end{array}$
\end{tabular}

You do not get the job done by Finance, HR (copies get lost), procurement (buying something from them takes decades).

Table $4 \mathrm{a}$ and $4 \mathrm{~b}$ indicates strong significant intercorrelations between the statement that both administrative and academic work collectively and job categories at a significant value of 0.000 (chi-square). Although the cross-tabulation table reveals that $40 \%$ of the academic staff members did not agree with the statement, $91 \%$ of academic support staff and $51 \%$ of administration supported it.

\section{Discussion of research results}

The objective of the study was to explore the impact of leadership traits on the realisation of the transformation agenda in a merged and incorporated university. This is evident in the disproportionately high percentage of respondents who supported the view that independent thinking and freedom of speech were promoted, which was overshadowed by a strong disagreement that leaders in the university create platforms for open debates. Academic staff members, who constituted the highest proportion in the university, disagreed with the view that platforms for open debates were created. However, a number of leaders partly disputed the previous findings by stating that there was excessive consultation and involvement of stakeholders, while implementation, monitoring and evaluation of the impact were inconspicuous. The previous finding is in disagreement with Ramphele (2008) who posits that open debates provide solutions facing universities in South Africa and Zide (2010), who claims open debates are an integral part of the transformation agenda. Findings on the freedom of speech and independent thinking are contrary to those of McGrath (2015) that freedom in universities has diminished in recent years.

Strong disagreement that leaders in the university create platforms for open debates is incongruent with Thomas and Thomas's (2011) argument that leaders should utilise critical and constructive debates and think outside the box in order for universities to be successful. Findings from the structured questionnaire supported the argument that leaders create avenues for personal development. This was disputed by a number of interviewees through in-depth interviews, who said personal growth happens accidentally and sporadically in the university, with no impact on the university's performance as monitoring and evaluation of the impact was not conducted. This finding concurs with Ngcamu and Teferra's (2015a:130) findings in the same university that skills development programmes were countertransformational, irrelevant, sporadic and irresponsive to the training needs of the university leaders.

It is, however, intriguing that while independent thinking and freedom of speech scored high on the agreement dimension, the perception that decision-making was centralised in this university was also high (43\%). This was supported by findings of the interviews, citing weak devolution and delegation of power by university leaders. Centralised decision-making support is against the view held 
by several researchers (Chen \& Silverthorne 2005; Coates et al. 2010; McGrath 2015) who are in favour of devolved, participative and transparent decision-making as this increases job satisfaction, morale, productivity and customer service. Worth noting in this study is academic leaders' dissatisfaction with the ineffectiveness and inefficiencies of administrative staff, which accords with researchers who claim academics bemoan the lack of support from administrators (Holton \& Philiphs 1995): that there is an uneasy and ambivalent relationship (McInnis 1998) and that administrative staff are stuck in slow motion and ignoring efficiency (Kuo 2009). The study results show that leadership traits espoused by a number of authors (Bass 2008; McCrae \& Costa 1987; Stodgil 1948) are not available or little used by university leaders, which has adversely affected transformation in this university.

\section{Conclusion}

This article observed that in this university, freedom of speech and independent thinking do not guarantee that the university leaders will permit open debates amongst the university leaders. The study found that some traits emanating from the leadership theory, including openness, were not encouraged by university leaders in effecting transformation. Freedom of speech and independent thinking cannot be confirmed to be promoted in the university as implementation, monitoring and evaluation of employed inputs during excessive consultations cannot be measured and are not considered by the decisionmaking structures. This is similar to the skills development programmes, which were regarded as irresponsive to leaders' training needs and cannot be regarded as valuable as monitoring and evaluation of the impacts were not conducted on the leader's performance in the aftermath of these trainings. Therefore, this study concludes that lack of monitoring and evaluation on leadership traits' effect on transformation prevents institutions realising their transformation agenda. However, the fundamental constitutional rights of independent thinking, freedom of speech, open debates and decentralised decision-making had little effect on transformation, post merger and incorporation. This article concludes that open debates as a leadership trait are encouraged in this university for compliance purposes, with no intention to realise the transformation agenda. This study further concludes that in this university, decision-making is centralised which is a very important leadership trait, clearly corroborating the findings that freedom of speech, open debates and independence are not promoted and this impinges on leaders realising the institutional transformation agenda. Finally, this article concludes that relationships between academics and administrative staff members were poor as they were at a lower level. This is clear sign that the university was not following the transformation trajectory. This study is pivotal as there is no scholarly study conducted in universities investigating the leadership traits' effect on transformation.

The limitations of this study are related to the literature and methodology. There is a dearth of published literature on leadership traits' effects on transformation in HEIs in
South Africa. Furthermore, literature on the role of meetings and productive interventions for change, as drivers of transformation, is scant. There is also paucity of published data on the biographical influence on transformation in HEIs. It is suggested that future researchers conduct studies using open-ended questions and focus group discussions in order to triangulate their findings. In order to address the identified gaps that have potential effects on the transformation in the university, the following recommendations are made:

- University leaders should learn, link and listen to younger employees and create robust debates on transformational issues with the aim to participate in and own transformation activities.

- University leaders should have an open door policy with a clear communication plan, which will increase the visibility and accessibility of the leaders for stakeholders to air their views, suggestions and uncertainties about transformation initiatives without any fear.

- The university should develop an internal management development programme for employees aspiring to occupy supervisory positions in the HEI.

- The university should develop a three-layered leadership development programme for junior, middle and executive positions in order to effectively, efficiently and economically influence the transformation agenda. Leaders' performance should be monitored during and evaluated at the end of the programme.

- The human resources department should initiate and implement an all-inclusive performance management system with clearly spelt out pecuniary and nonpecuniary performance rewards for all staff.

- Rigid bureaucratic business processes should be reengineered by line managers and replaced by smooth, flexible and responsive ones that are aligned with the institutional policies, structures and the transformation agenda of the university and the country.

- Change management interventions, including the use of the business process engineering or management principles, should be conducted by change agents with clear output or outcome measures which are based on the institutional and national transformation agenda.

- For the university to realise the transformation agenda, both experienced and inexperienced academic and administrative leaders should participate in making important decisions for their departments and faculties.

\section{Acknowledgements Competing interests}

The authors declare that they have no financial or personal relationships which may have inappropriately influenced them in writing this article.

\section{References}

Abrahamson, E., 2004, Change without pain, Harvard Business School Press, Boston, MA.

Aggarwal, S., 1998, 'Re-engineering: A breakthrough or little new?' Journal of SocioEconomic Planning Science 32(2), 155-167. https://doi.org/10.1016/S00380121(97)00006-2 
Amzat, I.H. \& Idris, D.A.R., 2012, 'Structural equation models of management and decision-making styles with job satisfaction of academic staff in Malaysian Research University', International Journal of Educational Management, 26(7) 616-645. https://doi.org/10.1108/09513541211263700

Anderson, D.R., Sweeney, D.J. \& Williams, T.A., 2006. Essentials of statistics for business and economics, Thomson South-Western, Mason, $\mathrm{OH}$

Asmal, K., 2002, Ministry of Education 2002. Standard Institutional Statute, Government Gazette No. 23061, Notice 85, 25 January 2002, Government Printers, Pretoria.

Avolio, B.J., 2005, Leadership development in balance: Made/born, Psychology Press, Hove.

Babbie, E. \& Mouton, J., 1998, The practice of social research, Oxford University Press, Oxford.

Babbie, E. \& Mouton, J, 2001, The practice of social research, Oxford University Press, Cape Town.

Babbie, E., 2004, The practice of social research, Wadsworth, Thomson Learning Inc., Belmont, CA.

Barker, R.A., 2001, 'The nature of leadership', Human Relations 54(4), 469-494. https://doi.org/10.1177/0018726701544004

Bass, B.M., 2008, The bass handbook of leadership: Theory, research, and managerial applications, 4th edn., Free Press, New York.

Bono, J.E. \& Judge, T.A., 2004, 'Personality and transformational and transactional leadership: A meta-analysis', Journal of Applied Psychology 89(5), 901-910. https://doi.org/10.1037/0021-9010.89.5.901

Bowen, G.A., 2009, 'Document analysis as a qualitative research method', Qualitative Research Journal 9(2), 27-40. https://doi.org/10.3316/QRJ0902027

Bryman, A., 2004, 'Qualitative research on leadership: A critical but appreciative review', The Leadership Quarterly 15(6), 729-769. https://doi.org/10.1016/j leaqua.2004.09.007

Bryman, A., 2007, 'Effective leadership in higher education: A literature review', Studies in Higher Education 32(6), 693-710. https://doi.org/10.1080/0307507070 1685114

Carlyle, T., 1869, Heroes and hero-worship, Chapman and Hall, London.

Chalufu, S., 2002, 'The merger of KwaZulu-Natal technikons', in J.D. Jansen (ed.), Mergers in higher education: Lessons learned in transitional contexts, UNISA Press, Pretoria, pp. 1-12.

Charney, C., 2006, The leader's tool kit: Hundreds of tips and techniques for developing the skills you need, AMACOM, New York.

Chen, J.C. \& Silverthorne, C., 2005, 'Leadership effectiveness, leadership style and employee readiness', Leadership \& Organization Development Journal 26(4), 280288. https://doi.org/10.1108/01437730510600652

Coates, H., Dobson, I.R., Goedegebuure, L. \& Meek, L., 2010, 'Across the great divide: What do Australian academics think of university leadership? Advice from the CAP survey', Journal of Higher Education Policy and Management 32(4), 379-387. https://doi.org/10.1080/1360080X.2010.491111

Cohen, L., 2006, 'Brain drain claims at merger-university', Sunday Argus, 18 June, p 1.

Costa, P.T. Jr, Terracciano, A. \& McCrae, R.R., 2001, Gender differences in personality traits across cultures: Robust and surprising findings', Journal of Personality and Social Psychology 81(2), 322-331. https://doi.org/10.1037/0022-3514.81.2.322

Council on Higher Education \& Education Quality Committee, 2008, Report of the HEQC to the Durban University of Technology, Higher Education South Africa, Pretoria.

Creswell, J.W. \& Zhang, W., 2009, 'The application of mixed methods designs to trauma research', Journal of Traumatic Stress 22(6), 612-621. https://doi. trauma research', Journc
org $/ 10.1002 /$ jts.20479

Daft, R., 1983, 'Learning the craft of organisational research', Academy of Management Review 8(4), 539-546.

Davis, A., Jansen van Rensburg, M. \& Venter, P., 2014, 'The impact of managerialism on the strategy work of university middle managers', Studies in Higher Education (ahead-of-print) 41(8), 1-15.

De Lange, N. \& Olivier, M.A.J., 2008, 'Nurturing human capital: A challenge for higher education institutions?', South African Journal of Higher Education 22(1), 41-63. https://doi.org/10.4314/sajhe.v22i1.25773

Derue, D.S., Nahrgang, J.D., Wellman, N.E.D. \& Humphrey, S.E., 2011, 'Trait and behavioral theories of leadership: An integration and meta-analytic test of thei relative validity', Personnel Psychology 64(1), 7-52.

Ensor, P., 2004, 'Contesting discourses in higher education curriculum restructuring in South Africa', Higher Education 48(3), 339-359. https://doi.org/10.1023/B:HIGH. 0000035544.96309.f1

Fourie, M., 1999, 'Institutional transformation at South African universities: Implications for academic staff', Higher Education 38, 275-290. https://doi. org/10.1023/A:1003768229291

Francis, D. \& Hemson, C., 2010, Shadows of transformation: Inclusion and exclusion of academic staff at a university of technology', SAJHE 24(6), 875-880.

Fullan, M. \& Scott, G., 2009, Turnaround leadership for higher education, John Wiley \& Sons, Hoboken, NJ.

Ghauri, P. \& Gronhaug, K., 2005, Research methods in business studies, 3rd edn., FT* London.

Green, M.F. \& Hayward, F.M., 1997, 'Forces for change in transforming higher education', in M.F. Green (ed.), Transforming higher education, Oryx Press, Phoenix, pp. 33-45.
Hall, M., Symes, A. \& Thierry, L., 2004, The Governance of Merger in South African Higher Education: Research Report prepared for the Council on Higher Education, Council on Higher Education, Pretoria.

Hay, D. \& Fourie, M., 2002, 'Preparing the way for mergers in South African higher and further education institutions: An investigation into staff perceptions', Higher Education 44, 115-131. https://doi.org/10.1023/A:1015569229047

HEIAAF Task Team, 2008, Report on higher education, institutional autonomy and academic freedom, Council on Higher Education, Pretoria.

Heifetz, R.A., Kania, J.V. \& Kramer, M.R., 2004, 'Leading boldly', Stanford Socia Innovation Review 2(3), 20-32.

Hemson, C. \& Singh, P., 2010, 'Shadows of transformation: Inclusion and exclusion of academic staff at a university of technology', SAJHE 24(5), 935-952.

Herbst, T.H.H., \& Conradie P.D.P., 2011, 'Leadership effectiveness in Higher Education: Managerial self-perceptions versus perceptions of others', South African Journal of Industrial Psychology 37(1), 1-14. https://doi.org/10.4102/sajip.v37i1.867

Holton, S.A. \& Phillips, G., 1995, 'Can't live with them, can't live without them: Faculty and administrators in conflict', in S.A. Holton (ed.), Conflict management in higher education, New Directions for Higher Education 92, 43-50.

Jago, A.G., 1982, 'Leadership: Perspectives in theory and research', Management Science 28(3), 315-336. https://doi.org/10.1287/mnsc.28.3.315

Jansen, J.D., 2003, 'On the state of South African universities: Guest editorial', South African Journal of Higher Education 17(3), 1-9.

Jansen, J.D., 2005, 'Targeting education: The politics of performance and the prospects of "Education for All"', International Journal of Educational Development 25(4) 368-380. https://doi.org/10.1016/j.ijedudev.2005.04.009

Judge, T.A., Bono, J.E., llies, R. \& Gerhardt, M.W., 2002, 'Personality and leadership: A qualitative and quantitative review', Journal of Applied Psychology 87(4), 765780. https://doi.org/10.1037/0021-9010.87.4.765

Kavanagh, M.H. \& Ashkanasy, N.M., 2006, 'The impact of leadership and change management strategy on organisational culture and individual acceptance of change during a merger', British Journal of Management 17(Suppl 1), S81-S103. https://doi.org/10.1111/j.1467-8551.2006.00480.x

Keinde, I., 2013, 'Coaching leadership traits preferences of university and college athletes', International Journal of Social, Behavioral, Educational, Economic, Business and Industrial Engineering 7(11), 2935-2939.

Kirkpatrick, S.A. \& Locke, E.A., 1991, 'Leadership: Do traits matter?' The Executive 5(2), 48-54. https://doi.org/10.5465/AME.1991.4274679

Kulati, T., 2000, 'Governance, leadership and institutional change in South African higher education: Grappling with instability', Tertiary Education and Management 6(3), 177-192. https://doi.org/10.1080/13583883.2000.9967022

Kuo, H., 2009, Understanding relationships between academic staff and administrators: An organisational culture perspective', Journal of Higher Education Policy and Management 31(1), 43-54. https://doi.org/10.1080/13600800802559278

Labuschagne, A., 2003, 'Qualitative research: Airy fairy or fundamental?' The Qualitative Report 8(1), 1-12.

Lewis, K., Kaufman, J. \& Christakis, N., 2008, 'The taste for privacy: An analysis of college student privacy settings in an online social network', Journal of Computer Mediated Communication 14(1), 79-100. https://doi.org/10.1111/j.1083-6101. 2008.01432.x

Lord, R.G., De Vader, C.L. \& Alliger, G.M., 1986, 'A meta-analysis of the relation between personality traits and leadership perceptions: An application of validity generalization procedures', Journal of Applied Psychology 71(3), 402. https://doi. org/10.1037/0021-9010.71.3.402

Lumby, J., 2012, What do we know about leadership in higher education. Leadership Foundation for Higher Education, London.

Mabelebele, J., 2013, 'What are universities for? Lessons for the University of Venda (August)', Public Lecture delivered at the University of Venda, University Senate Chambers, Thohoyandou, South Africa.

Mann, R.D., 1959, 'The relation between personality characteristics and individual performance in small groups', Psychological Bulletin 56(4), 241-270. https://doi. org/10.1037/h0044587

Mat, J., 2008, The influence of leadership style on internal marketing in retailing, PhD thesis, University of Stirling.

May, T. \& Mason, R.B., 2007, 'Goal clarity and trust in management in educational mergers', Acta Commercii 7(1), 151-163. https://doi.org/10.4102/ac.v7i1.23

McCrae, R.R. \& Costa, P.T. Jr, 1987, 'Validation of the five-factor model of personality across instruments and observers', Journal of Personality and Social Psychology 52(1), 81-90. https://doi.org/10.1037/0022-3514.52.1.81

McCrae, R.R., 1987, 'Creativity, divergent thinking, and openness to experience', Journal of Personality and Social Psychology 52(6), 1258. https://doi.org/ 10.1037/0022-3514.52.6.1258

McGrath, J., 2015, The little book of big decision models: The 70 most useful models to help you say Yes or No, Pearson, New York.

McInnis, C., 1998, 'Academics and professional administrators in Australian universities: Dissolving boundaries and new tensions', Journal of Higher Education Policy and Management 20(2), 161-173.

McKenna, S., 2003, 'Paradigms of curriculum of curriculum designs: Implications for South African educators', Journal for Language Teaching 32(2), 215-223.

McMurray, A.M., Henly, D., Wendy, C., Clapton, J., Lizzio, A. \& Teml, M., 2012 'Leadership succession management in a university health faculty', Journal of Higher Education Policy and Management 34(4), 365-376. 
Meyer, H.D. \& Kaloyeros, A.E., 2005, 'What campuses can do to pick up the pace of decision making', The Chronicle of Higher Education, the Chronicle Review 51(40), B16.

Meyer, M. \& Botha, E., 2004, Organisation development and transformation in South Africa, LexisNexis Butterworths-Heinemann, Oxford.

Mintzberg, H., 1998, 'Covert leadership: Notes on managing professionals', Harvard Business Review 76, 140-148.

Moran, J.W. \& Brightman, B.K., 2000, 'Leading organizational change', Journal of Workplace Learning 12(2), 66-74. https://doi.org/10.1108/13665620010316226

Mumford, E., 1999, 'Routinisation, re-engineering, and socio-technical design Changing ideas on the organisation of work', in W.L. Currie \& B. Galliers (eds.) Rethinking management information systems: An interdisciplinary perspective, Oxford University Press, New York.

Murphy, M. \& Curtis, W., 2013, 'The micro-politics of micro-leadership: Exploring the role of programme leader in English universities', Journal of Higher Education Policy and Management 35(1), 34-44. https://doi.org/10.1080/1360080X.2012.727707

National Working Group (NWG), 2001, The restructuring of the higher education system in South Africa: Report of the National Working Group to the Minister of Education. Government Gazette No. 23549, 21 June 2002, Government Printers (Appendix 3 of the Notice), Pretoria.

Ng'ethe, J.M., Namusonge, J.S. \& Iravo, 2012, 'Influence of leadership style on academic staff retention in Public Universities in Kenya', International Journal of Business and Social Science 3(21), 297-302.

Ngcamu, B.S. \& Teferra, D., 2015a, 'Leadership and transformation in a South African university', Problems and Perspectives in Management 13(1), 208-216.

Ngcamu, B.S. \& Teferra, D., 2015b, 'Leadership features influencing transformation post-merger and incorporation era: A case of the Durban University of Technology' Journal of Governance and Regulation 4(1), 408-415. https://doi.org/10.22495/ jgr_v4_i4_c3_p5

Ngcamu, B.S. \& Teferra, D., 2015c, 'Leadership influence on institutional transformation in the post-merger and incorporation era: The case of the Durban University of Technology', South African Journal of Higher Education 29(5), 232-243.

Ngcamu, B.S. \& Teferra, D., 2015d, 'The effect of skills development programmes and leadership opportunities brought by transformation: A case of the Durban University of Technology', Journal of Social Sciences 45(2), 130-139.

Northouse, P. Guy, 2010, Leadership: Theory and practice, 5th edn., Sage, Thousand Oaks, CA.

Ntshoe, I.M., 2004, 'The political and economics of post-apartheid higher education transformation', Comparative Education Review 48(2), 202-222. https://doi. transformation, Com

Okumbe, J.A., 1998, Educational management: Theory and practice, Nairobi University Press, Nairobi.

Olayo, J.O., 2005, The impact of employee empowerment on work performance: Case study of selected universities in Kenya', unpublished MBA thesis, Kenyatta University.

Oloyede, O., 2007, Social transformation: Anatomy of a concept, paper presented to the Centre for Humanities Research, University of the Western Cape.

Powell, W.R. Jr., 2001, Theories of societal development and cross-cultural aspects of organisational change', Futurics. St. Paul 25(1/2), 1-26.

Ramphele, R., 2008, Laying ghosts to rest: Dilemmas of the transformation in South Africa, NB Publisher, Tafelberg.

Reddy, T., 2007, 'Staff perceptions of the merger between two South African regional technikons', South African Journal of Higher Education 21(3), 485-502.

Reis, C.T., 2015, 'Leadership traits of successful women university presidents', The Researcher 27(2), 14-19.

Republic of South Africa, 2002, Durban University of Technology Annual Report, DUT, Durban.

Republic of South Africa, 2013, Durban University of Technology Annual Report, DUT, Durban.
Rowley, J., 1996, 'Motivation and academic staff in higher education', Quality Assurance in Education 4(3), 11-16. https://doi.org/10.1108/09684889610125814

Saunders, M., Lewis, P. \& Thornhill, A., 2007, Research methods for business students, 4th edn., Pearson Education Limited, England.

Schultz, C.M., 2009, 'Building a human resource strategy for a merging higher education institution in South Africa', South African Journal of Labour Relations 33(2), 11-18.

Scott, G., Coates, H. \& Anderson, M., 2008, Learning leaders in time of change: Academic leadership capabilities for Australian higher education, University of Western Sydney, Australian Council for Educational Research, Sydney.

Seedat, J.S., Khoza-Shangase, K. \& Sullivan, L., 2014, 'Experiences of university students regarding transformation in South Africa', International Journal of Educational Management 28(1), 66-81. https://doi.org/10.1108/IJEM-012012-0017

Sekaran, U.,1992, Research methods for business: A skill-building approach, Wiley, New York.

Siddique, A., Aslam, H.D., Khan, M. \& Fatima, U., 2011, 'Impact of academic leadership on faculty's motivation, and organizational effectiveness in higher education system', International Journal of Business and Social Science 2(8), 184-191.

Singh, M., 2001, Re-inserting the 'public good' into higher education transformation, Kagisano CHE Higher Education Discussion Series 1, Pretoria.

Singh, P., 2011, 'Transformation and performativity in universities in South Africa', South African Journal of Higher Education 25(6), 1190-1204.

Solaja, M.O., Idowu, E.F. \& James, E.A., 2016, 'Exploring the relationship between leadership communication style, personality trait and organizational productivity', Serbian Journal of Management 11(1), 99-117. https://doi.org/ $10.5937 / \mathrm{sjm} 11-8480$

Soudien, C., 2008, Report on transformation and social cohesion and the elimination of discrimination in public higher education, Department of Education, Cape Town.

South Africa, 1967, Advanced Technical Education Act (No. 40 of 1967), Government Printer, Pretoria, South Africa.

South Africa, 1993, Technikon Act (No. 125 of 1993, Government Printer, South Africa, Pretoria.

South Africa, 1997, Higher Education Act (No. 101 of 1997), Government Printer, Pretoria.

South Africa, Government Gazette No. 18207, 15 August 1997, Government Printers, Pretoria, Section 2.1 .

Stodgil, R.M., 1974, Handbook of leadership: A survey of the literature, Free Press, New York.

Stodgil, R.M., 1948, 'Personal factors associated with leadership: A survey of the literature', Journal of Psychology 25, 35-71. https://doi.org/10.1080/00223980.1 literature, Journ

Thomas, H. \& Thomas, L., 2011, 'Perspectives on leadership in business schools', Journal of Management Development 30(5), 526-540. https://doi.org/10.1108/ 02621711111133037

Van der Merwe, H.M., 2007, 'The Vudec merger: A recording of what was and a reflection on gains and losses', South African Journal of Higher Education 21(3), reflection

Yukl, G.A., 2006, Leadership in organizations, 6th edn., Pearson Prentice Hall, Upper Saddle River, NJ.

Zaccaro, S.J. \& Banks, D., 2004, 'Leader visioning and adaptability: Bridging the gap between research and practice on developing the ability to manage change' Human Resource Management Journal 43, 367-380. https://doi.org/10.1037/ 0003-066X.62.1.6

Zide, G.N., 2010, A diagnostic approach to organisational transformation: A higher education response, Vaal University of Technology, Vanderbiljlpark. 